This item was submitted to Loughborough's Research Repository by the author.

Items in Figshare are protected by copyright, with all rights reserved, unless otherwise indicated.

\title{
Being out of place: Non-belonging and queer racialization in the U.K.
}

PLEASE CITE THE PUBLISHED VERSION

https://doi.org/10.1016/j.emospa.2018.02.008

\section{PUBLISHER}

(c) Elsevier

\section{VERSION}

AM (Accepted Manuscript)

\section{PUBLISHER STATEMENT}

This paper was accepted for publication in the journal Emotion, Space and Society and the definitive published version is available at https://doi.org/10.1016/j.emospa.2018.02.008.

\section{LICENCE}

CC BY-NC-ND 4.0

\section{REPOSITORY RECORD}

Dasgupta, Debanuj, and Rohit Dasgupta. 2019. "Being Out of Place: Non-belonging and Queer Racialization in the U.K.". figshare. https://hdl.handle.net/2134/32136. 


\title{
Being out of place: Non-belonging and queer racialization in the U.K.
}

\author{
Debanuj DasGupta ${ }^{\mathrm{a}}$, Rohit K. Dasgupta ${ }^{\mathrm{b}, *}$ \\ ${ }^{a}$ University of Connecticut, Department of Geography and Women's, Gender, and Sexuality Studies, United States \\ ${ }^{\mathrm{b}}$ Institute for Media and Creative Industries, Loughborough University, United Kingdom
}

\begin{abstract}
A B S T R A C T
The question of refugee rights and immigrant entry to the UK presently has come under attack with the rise of nationalist sentiment and the exit of the UK from the European Union. The figure of the Muslim migrant has been normatively constructed to represent a limit to UK's multiculturalism (and, arguably globally). Such anti-Mus- lim sentiment operates via displacing racialized bodies from UK public culture. This article situates the ways in which racialized queer Muslim subjects attempt to maneuver structural racism and heteronormativity in the UK. The article argues that queer Muslim immigrants perceive queer spaces in Central London as white spaces. Sec- ondly, we will analyze how the racialized queer Muslim subject creates ethnoracial specific spaces that are lo- cated outside central London. We argue that queer migration needs to be understood as an embodied experience by paying attention to how racialized queer Muslim migrants moves through multiple spaces in the city. The article develops a mixed method approach through an analysis of Ian Iqbal Rashid's film A Touch of Pink (2004) alongside Raisa Kabir's recent exhibition In/Visible Space: Reflections on the Realm of Dimensional Affect, Space and the Queer Racialised Self (Rich Mix, April, 2013) and the narrative of a gay identified working class Muslim im- migrant male from East London. We argue that queer Muslim migrants reside on the margins of British symbolic culture through a non-belonging to one's religious identity. Such non-belonging is a spatialized experience. An analysis of the film, exhibition and our ethnography reveals the ways in which sexuality is constructed and con- ferred through racialization and creates precariously situated queer Muslim migrant subjects within present day UK.
\end{abstract}

\section{Introduction}

The question of refugee rights and immigrant entry to the UK presently has come under attack with the rise of nationalist sentiment and the exit of the UK from the European Union. The figure of the Muslim migrant has been normatively constructed to represent a limit to UK's multiculturalism (and, arguably globally). Such anti-Muslim sentiment operates via displacing racialized bodies from UK public culture. This article situates the ways in which racialized queer Muslim subjects attempt to maneuver structural racism and heteronormativity in the UK.

In this article, we analyze the representation of queer Muslim subjectivity in relationship with the representation of the city-scape and diverse neighborhoods of London within Ian Iqbal Rashid's film A Touch of Pink (2004), the photographic exhibition In/Visible Space by British

Asian artist Raisa Kabir, and an ethnographic vignette from a queer working class immigrant Muslim male in East London. We argue that the formation of the queer Muslim racialized subjectivity is a spatialized process one that situates queer Muslims on the peripheries of gay (white) spaces of central London. Secondly, through an analysis of Rashid's A Touch of Pink, we discuss how transnational migration and racialized regimes of immigration control is felt at the scale of the body and everyday life by queer Muslim subjects. We will juxtapose the film with Raisa Kabir's exhibit along with an interview of Usman, a queer Muslim working class gay man living in Plaistow, East London. This juxtaposition of diverse cultural texts and Usman's narrative allows for a fuller understanding of how the framing of Islam as a backward religion works to racialize the queer Muslim subject as always needing to disavow their religion. In conclusion, we will argue that recent coalitional queer Muslim cultural activism such as the work of Kabir might gesture us toward different possibilities, wherein queer Muslim migrant subjects need not disavow their ethno-religious identity and spaces.

The article is divided into three major sections. In the first section, we analyze the cinematic depiction of $A$ Touch of Pink in order to situate the psychic horizon of the queer Muslim male figure. This section 
argues that both Nuru (Alim's mother) and Alim are queer figures, since their desires for a livable life exceeds the racialized landscape of London. Further, we pay keen attention to the stories of chain migration from Mombasa, Kenya to London, England and then to Toronto, Canada in order to situate spatialized narratives of Muslim migrants. We argue that ideas about being in place or out of place for queer Muslim migrants in present day UK needs to be understood as always framed through multi scalar transnational travel (also see Kuntsman and Miyake, 2008). The movement through three continents continuously situate the Muslim migrant community on the margins of Western Europe and outside the promise of gender and sexual autonomy, a hallmark of liberal modernity. The film comes to represent how racialized queer subjects attempt to maneuver structural racism and heteronormativity in the UK.

The second section of the article, contrasts Rashid's hopeful finale in A Touch of Pink wherein Nuru comes to term with Alim and Giles, as she finds a suitor for herself with the narrative of a gay identified working class immigrant male from East London. In our interview, he identifies the city center of London as the utopian gay core mediated through class and whiteness. He travels to the bars of city center in order to create a queer space which is otherwise unavailable to him in the immigrant neighborhood of his residence. He has to disavow Islam, in order to navigate the gay spaces in London. His travel between two sections of the city comes to signify the traffic between the promised gay modernity of UK and the unassimilability of Islam within the liberal modernity of UK.

The final section of the article analyzes the photographic work of British-Bangladeshi artist Raisa Kabir. Kabir's work presents a montage of images. Her photographs capture South Asian immigrant spaces in London such as immigrant neighborhoods, bazaars, and Mosques. She juxtaposes traditional images of the Mosque with Maryam, a self-iden-

tified lesbian-feminist praying at the mosque. The juxtaposition of Maryam's images with that of the Mosque challenges the notion that places of worship and ethnic community spaces (termed as Brown spaces by Kabir) are homophobic. In this way Kabir re-spatializes queer brown bodies within immigrant London. While being in the core of the gay Metropolis requires a disavowing of one's religion, being in the immigrant suburbs of the city might hold potentials for offering a queer space for Muslim immigrants who otherwise remain positioned on the margins of U.K. and its imagined liberal modernity (also see DasGupta, 2014). Through an analysis of multiple texts and vignettes from our interview with a queer Muslim working class immigrant, the article argues that queer geographic scholarship needs to take into consideration how histories of colonialism, racialized migratory regimes is felt at the scale of the body by queer Muslim migrant subjects.

Questions of how queer space is formed and contested needs to be understood through how race and sexuality are co-constitutive of each other. In doing so, the article attempts to bring together queer of color critique (Ahmed, 2010; Gopinath, 2005; Puar, 2007), queer geographic scholarship (Browne et al., 2007; Gorman-Murray, 2009; Oswin, 2008; Rouhani, 2007) and recent feminist approaches to geopolitics (Pain, 2009; Pain and Smith, 2008; Pain and Staeheli, 2014) and literature on queer migration (Chavez, 2013; Gorman-Murray, 2007; Lubheid, 2008) as a way of interrogating the co-constitution of space and racialized Muslim subjectivity within present day UK.

\subsection{A note on methodology}

Methodologically speaking, the article attends to the cultural turn in geography by building upon the critical cultural studies tradition of the Birmingham school, particularly the work of Stuart Hall. Following Hall's ideas about the formation of new racialized blocks in post 1960's UK and tracing the logics of advanced capitalism within cultural representations (Hall, 1988, 1993) we trace the representation of the Lon- don city-scape in Rashid's $A$ Touch of Pink, and Kabir's exhibition along with the interviews with Usman. Throughout the article we will argue that by interrogating affective representations of diverse neighborhoods of London within queer Muslim narratives, we can understand sexual identity is conferred upon the queer Muslim subject through a disavowal of religious and ethnic identities. In a word we trace the relationships between migration, racial regulations, and sexual identity formation within queer Muslim subjects through an analysis of how the city-scape of London is represented in diverse cultural texts. We do not suggest that the interview with Usman and cultural representation in the film and photographic exhibitions are similar in nature. Rather, following Hall we read the interview, the film, and the exhibit as cultural texts. Hall writes that identity formation is a complex process, with both cultural representation and the subject's narration about self and identity best understood as cultural process that is formed through the power inequalities of every society (Hall, 1993). Our methodologies also derive from Gayatri Gopinath's (2005: 22) 'scavenger methodology' and Sharif Mowlabocus' (2010:7) 'magpie methodology', offering a queer reading of these diverse cultural texts. Gopinath (2005: 22) argues, 'queerness references an alternative hermeneutic, the particular interpretive strategies that are available to those who are deemed "impossible" within hegemonic nationalist and diasporic discourses'. For Gopinath, the category 'queer' names a reading practice which she deploys to read multiple cultural texts. We employ a queer hermeneutics of the multiple texts (interviews, film and exhibition) in order to situate the ways in which racialized queer Muslim subjects attempt to maneuver structural racism and heteronormativity in the UK.

\subsection{Happy orientations}

In his 2004 romantic comedy $A$ Touch of Pink writer/director Rashid presents the story of Alim (played by Jimi Mistry), a young gay Ismaili immigrant living in a fashionable part of London with his boyfriend Giles. Alim and Giles are both portrayed as upwardly mobile middle class gay men. Alim's affective life revolves around his boyfriend Giles and imagined companion Cary Grant, played by Kyle MacLachlan until his mother arrives from Canada in order to convince him into getting married to a woman. Alim's happy gay world is thrown into a disarray as his traditional Muslim mother begins to question his Gora (white) lifestyle.

Rashid's A Touch of Pink tells us the story of Alim and his orientation toward certain objects that generate happy feelings. Sara Ahmed argues that happiness is a kind of affect that is generated from someone or something else other than the subject and to be affected by something is to pass a judgement about something, "to be happy about something makes something good" (Ahmed, 2010: 32). The goods that makes Alim feel good are entangled with his romantic life. Alim's romance is not only with his boyfriend Giles, but also with an imaginary relationship with Cary Grant (arguably one of the most emblematic figure of Hollywood's white-masculinity). Grant's imaginary figure mediates Alim's conflicts with his mother, and helps him to effectively navigate his relationship with Giles. In this way, Alim's imaginary entanglement with the figure of Cary Grant comes to occupy a significant psychic space. As the film proceeds, we (the audience) learn that Alim's mother Nuru had run away to London (from Toronto, Canada) after the death of her husband. After her return, Alim grew distant with his mother. As Nuru would put it later in the film, "not a single world, only a pair of eyes, as you would silently play with your sailboat." The sailboat is one of Alim's favorite objects from a Cary Grant film. At a crucial moment in the film, when Alim and Nuru are in the midst of a fight, Alim retrieves into his imagined world with Grant watching some of his favorite films and playing with the sailboat. The sailboat comes to signify an object that stands for Cary Grants' figure, one that gener - 
ates happiness for Alim. As opposed to his relationship with Grant, his relationship with Nuru generates sad feelings. Nuru reminds him of his religious and ethnic origin one that puts him out of place from his white gay upper-class London world. Alim's placelessness is framed through a long history of imperialism, colonialism, and movement of South Asian immigrants across multiple continents (Gopinath, 2005). Alim's family were displaced from Mombasa, Kenya soon after its independence from British rule. Alim's extended family moved to Toronto, Canada, and Alim moved away from Toronto to London in search of a queer space. Alim and his family's journey is framed through the British Empire, one that brought Indian laborers to Kenya in order to build the railroads. Indian immigrants were required to become Kenyan citizens post-independence. Many failed to become citizens and were forced out of Kenya. Following this forced expulsion, several Indian communities settled across Canada, USA, and the UK. Alim's placelessness therefore is a product of colonialism and imperialism as depicted through the classic Cary Grant movie "Gunga Din.” In this 1939 Hollywood blockbuster based upon Rudyard Kipling's poem Gunga Din, three British soldiers valiantly fight off Indian burglars with the help of their loyal elephant (water-bearer). In A Touch of Pink the figure of Cary Grant nostalgically recalls the movie, conjuring the days of the British Empire and its colonialist racial scripts. Such a racialized script frames Alim's present day location across three continents.

The filmmaker knits Nuru's story along with Alim's journeys as a significant subplot, and as we will argue perhaps another main plot in the movie. The movie begins with our introduction to Grant and Alim's affective entanglement. Simultaneously, Rashid also takes us to Canada where Nuru, and her sister are planning Alim's cousin's wedding. Nuru looks yearningly at the elaborate floral arrangements, and the wedding cake. Her yearning suggestive of her emptiness since Alim is gone to London, and yet to marry a woman. Nuru tells everyone at the wedding that Alim is courting a woman in London in order to ward off questions from curious relatives. The yearning of an immigrant mother for her son's wedding, and the son's escape within a utopic world of friendship with Cary Grant frames the rest of the movie. Nuru visits Alim in London in attempts of convincing him to marry an Ismaili woman of her choice. Alim removes all proof of his homosexuality (including his relationship with Giles) from the house. The figure of Cary Grant oversees this process, as he reminds Alim that Nuru is a "Muslim woman from third world who will not understand homosexuality." We argue Grant's voice comes to represent the symbolic disavowal of Islam that Alim's character has to undergo in order to assimilate into the white upper class gay landscape of London. Alim's disavowal of his mother is symbolic of the racialized queer Muslim subjects' disavowal of all things "third world." Such an intimate disavowal within a highly Islamophobic UK becomes necessary for self-preservation reminding us that the affective field of registers is always connected to "power geometries" (Tolia-Kelly, 2006). Alim's affective orientation is mediated through the ways Islam is framed as a barbaric, backward gazing religion globally (Puar and Rai, 2004). Islam is imagined always as an alterity to European modernity, or yet to achieve modernity (Butler, 2010). In this way those of Islamic origin are thought of as childlike, of another time, yet to develop into modern adults. In A Touch of Pink Alim becomes a child in relation to his imaginary friend Cary Grant. Alim is learning to become a happy adult gay man under Grant's tutelage. Grant's tutelage requires him to grow distant from his religion and mother (land). Alim hopes to get rid of his mother during her trip to London at times by being rude, and finally by outing his intimate life with Giles. In this way Grant, Nuru, and Alim come to represent the strife between the promised sexual modernity of Western Europe and the backwardness of Islam.

As the film proceeds we learn about Nuru's desires for finding herself. She had escaped to London after the death of her husband, seeking opportunities beyond what her religion and ethnic migrant community might provide her. Her religious and immigrant background frames her gender role, and years later disable her son Alim's homosexual desires. Both the mother and son are caught between their desires and the limitations of their heteronormative religious and immigrant community. Their religious and ethnic background are depicted to be in opposition to the liberal promise of UK and Canada, positioning them on the margins of liberal modernity. The turmoil between religion, sexuality, and gendered expectations is a racialized process, one that is connected to longer histories of colonialism and imperialism that frames the Muslim migrant always on the margins of Western Europe. The final scene offers a resolution for Alim, his boyfriend, as well as his mother. Alim decides to attend his cousin's wedding as a way of making amends with his mother. Giles follows Alim to Toronto in hopes of resolving their conflicts. The movie comes to a climactic end with Alim kissing Giles in the middle of an elaborate Indian wedding, while Nuru proudly introduces Giles as Alim's partner. Nuru confronts the heteronormative constraints of her religion in order to accept her son's gay relationship. Nuru herself finds a suitor, in an immigrant Indian man who works in her apartment as a maintenance manager. The filmmaker ends $A$ Touch of Pink on this hopeful note and suggests potential happy horizons for both Alim and Nuru. Alim bids farewell to the figure of Cary Grant as a way of suggesting that all of his psychic conflicts have been resolved through 'coming out' to his mother and his entire Ismaili Muslim community. The agentic Muslim subject has to confront (their) religious and ethnic community and carve out a utopian space (represented through Nuru's apartment in the movie), one that remains forever out of place from ethnic immigrant spaces (also see Boyce and Dasgupta, 2017).

Rashid's cinematic representation of the Ismaili community comes after his first independent production, Surviving Sabu (1997), a diasporic father and son narrative. Surviving Sabu was an oedipal narrative of father-son relationship, and the tacit desire for masculinity within the emasculated immigrant male subject (Dasgupta and Gokulsing, 2014; Gopinath, 2005). In A Touch of Pink, Rashid takes up the theme of the mother-son dyad under the shadows of the absent father figure, while taking his viewers through a cinematic journey into the worlds of Ismaili Muslim immigrant community across Canada and the UK. The recollections of Nuru and her brother-in-law of their families' migration from Mombasa to Toronto under the threat of Idi Amin, shows us how Rashid seeks to represent the embodied experiences with migration. Alim is haunted with this inter-generational migratory experience. He wishes to disavow and just become a happy gay subject in present day UK. However, in one of the scenes Rashid shows us how Alim is reminded of his Muslim heritage at one of the Central London bars. Gile's sister throws a surprise birthday bash for the couple at a gay bar (named Ramrod in the movie). The set conjures a gay bar in Central London. As Alim dances away, one of Gile's ex-lovers satirically says "Aslam Alaikum" (Urdu greeting) to Alim, and makes light of his Muslim heritage. Throughout this section, we argue how in different ways Alim and Nuru's everyday life is shaped through their experiences with transnational migration and racialized regimes that frame queer Muslim subjects as always backward and outside liberal modernity. Feminist scholars of geopolitics such as Rachel Pain (2009) argues that affects such as fear and anxiety with the war on terror frame everyday lives, and geopolitics is not just a disembodied macro-geographic process between nation states. Rather, according to Pain and Smith fear of racialized bodies in the age of war on terror is lived and made through everyday experiences (Pain and Smith, 2008). As we argue through our analysis of Rashid's A Touch of Pink both Alim and Nuru are cast as queer subjects. Alim's religion renders him as an incomplete gay subject, one who needs the tutelage of his white savior (the spectral presence of Cary Grant). Alim is ultimately required to disavow his religious-ethnic identity in order to be read as appropriately gay. 
Whereas, Nuru is read as a failure within the compulsory heterosexuality of her Ismaili community, since she is neither capable of being a good mother nor is attached to any man through a marriage. Both Nuru and Alim are depicted to abandon their Ismaili community in order to carve out a utopic space for themselves. In contrast to Rashid's fantastic resolution of the conflict between religion and sexuality, we now turn to the narrative of Usman, an immigrant working class gay identified man living in East London. We argue that Usman's narrative reveals that Muslim gay subject while attempting to create a queer space within London's gayborhoods always remains situated on its margins. Usman's journey and placelessness is an embodied experience, one that puts him in or out of space. Unlike the English educated, cosmopolitan Alim from A Touch of Pink, Usman's place in UK always remains on the margin (in this case East London).

\subsection{Gay, muslim, and working class on the edges}

There has been very little scholarship on the Queer South Asian diaspora in the United Kingdom (Dasgupta, 2017; Dudrah, 2012; Yip, 2004). Whilst there are some celebrated films which have had queer South Asian characters such as Stephen Frear's My Beautiful Launderette (1985) Pratibha Parmar's Nina's Heavenly Delights (2006) and the queer Syed Masood-Christian Clarke storyline in the long running soap opera EastEnders these have been few and far between. In case of the EastEnders storyline, BBC received several complaints and became a divisive issue even as late as 2012. However all of these dealt almost exclusively with characters who were of South Asian origin but born and living in the United Kingdom. Our ethnography and interview with Usman who is a queer migrant offers a different reality from these movies and especially from Rashid's Touch of Pink which we discussed earlier. Usman's reality of gay London is very different from the one Alim experienced in Rashid's film.

Usman is thirty six (36) and lives in Plaistow, East London. He moved to London eight years ago in 2008. Usman grew up in a lower middle class orthodox Muslim family from the Chandni Chowk area of Delhi. Growing up Usman always felt he was different and around the age of fifteen he had started to meet other guys in cruising areas of Delhi. By the time he turned eighteen his parents could no longer afford to send him to college and he left school to start work as a sales person going door to door selling cleaning products. Usman had already started to get pressured by his family to get a better job and get married to a girl and settle down in the next few years. It was around this time that Usman tried to delay the marriage procedure by first enrolling himself into an evening college and promising to settle down once he had a degree which would open up more chances in life. As Usman recounted:

'Family life in India is tough, especially when you are Muslim. We are a tightly knit group in Chandni Chowk and everyone knows everyone. My dad was ready to get me married to the daughter of a local mullah. My day started with going to the mosque and ended with praying before going to bed. It was really difficult trying to break out of this existence'

Usman like many other queer men has found it difficult to reconcile his sexuality and religion. The sense of belonging he felt through his community was fractured. On one hand the stricture of religion and the space of the mosque created a sense of belonging and community for him, on the other hand he was desperate to get out of here on account of his religion. The term community has itself been subject to enormous amount of critical debate (Anderson, 1983; Dasgupta, 2016; Valentine, 2001). Whilst traditionally, communities have tended to be understood as groups of people who are interconnected through faith, ethnicity, class, geographical proximity and nationality; communities are as much about being part of a group as outside it. As Johnston and
Longhurst (2010) have argued, that often communities privilege difference rather than unity and often one part of the identity needs to be suppressed in order for there to be a single rallying point of unity. Thus whilst Usman's Muslim identity was important for his family as a way of feeling connected to their surroundings and a sense of belonging, for Usman it also triggered anxiety over his sexuality. He explains:

'I am not sure why but I just wanted to reject being Muslim. I did not think it would sit with me being gay. For a long time I rejected being gay but the urge was too much.'

The incommensurability of religion and sexuality is an area of much debate (Habib, 2009; Nagar and Dasgupta, 2015; Yip, 2015) and as Usman's quote shows reconciling them was a difficult process. After completing his undergraduate degree, Usman tried to find a job in Dubai with a building construction firm but was warned by one of his 'lovers' that being a Muslim country he might have difficulty living as a gay man. By this time the pressure on him to get married was also growing. He finally met an agent who explained he could try to get into UK on a student visa and then decide to live there indefinitely. Usman managed to convince his parents to take a large loan of money from the bank, relatives, friends and his future parents in law to send him abroad to study so that he could come back and get a better job and settle down. Usman managed to enroll into a one year business program with a local college and after two unsuccessful attempts got his visa to enter the UK. At this point it would be important to point out that unlike Alim who was escaping 'compulsory heterosexuality' by moving to London; Usman was moving both due to economic reasons- 'of wanting to make something of myself' and 'to be free' as he recounted to us. As Andrew Gorman Murray (2009: 112) reminds us 'displacement is grounded differently for individual queer subjects, so that material journeys through space and time occur on a variety of scales and paths'. Queerness and queer migration in this context is not so much about the queer possibilities of the new city/country but also about the 'possibilities for making lives liveable' (Chavez, 2013: 6) both through economic and socialmeans.

When he moved to London his parents had set him up with some cousins and family friends who lived in the East Ham area of the city and Usman started living there in a tiny room which he shared with two other recent immigrants from Pakistan. Within a few days of moving, Usman found out about Soho, the popular gay district located in Central London and decided to go there, but his first experience at a popular gay bar- Village was not how he expected it to be. Usman explained that the moment he walked to the door he was stopped by the security who told him repeatedly that it was a gay bar and if he was sure he wanted to go in.

'It was humiliating and also quite surprising. I was standing outside wanting to go in but was being told repeatedly that this was a gay bar. Did they think I would not know or have they never seen Indians/Muslims come to a gay bar?'

Usman's experience is not much different from the ways in which gay bars often act as gated communities keeping out certain classed, gendered and coloured bodies (Dasgupta, 2017). The impossibility of Usman's brown and visible Muslim identity (his beard and clothes) marked him as a hostile outsider in the eyes of the club's management before he was even allowed to cross the threshold. For Usman this sense of non belonging in a space that he expected would understand and embrace him was a betrayal. When he did manage to enter the premises he did not feel the 'warmth of the community' that he was looking for. Instead as he recounted he felt stared at and when he did attempt to go and talk to some of the patrons there; rebuffed and told they could not understand him. There are now organizations such as the long running Naz Project London and more recently Imaan which 
offer services for queer men and women of South Asian and Muslim heritage (Dasgupta, 2018). When asked if Usman had ever sought their help in trying socialize with others like him, he told us he had not even heard of them.

As ethnographers, we encounter community mostly as a way people refer to their shared relation to a geographic space and place making practices. Thus, whilst early work by scholars such as Wayne Myslik (1996) recount the gay bar as a safe space and as a site of resistance, as Usman's experience shows this is far from true. The safe space being created for queer men in these spaces are racialised boundaries which attempt to keep people like Usman out; whose brown and Muslim identity threaten to dislocate the heterogenity of this supposed safe space. Furthermore when scholars such as Myslik (1996: 168) claim that 'queer spaces create the strong sense of empowerment that allows men to look past the dangers of being gay in the city and to feel safe and at home' one is left wondering how such a statement can capture Usman's disempowerment within such queer spaces.

One of the other ideas about the South Asian diaspora and its conservatism that Usman's story dismantles was his experience with his 'orthodox' room mates who asked him why he was going out every night and wanted him to tell the truth. At first Usman was worried that by coming out he could possibly be thrown out but then decided if that was to be, 'it won't be such a bad thing after all'. However he was taken by surprise when both these room mates heard him patiently and in- stead of being violent towards him simply said they would pray for him. Gopinath (2005) makes an important point about the diaspora and its conservatism. Citing Hall, she argues that whilst conventional diasporic discourse is marked by a backward glance for the times past, queer diasporas mobilize these questions of the past and nostalgia but for radically different purpose. Usman felt he was 'twice marginalized'- for being gay and Muslim but surprisingly what he did not expect was that other (white) gay men who he had thought of as his natural ally would so easily look over him and the very 'orthodox Muslims' he was trying to escape from in India would ultimately become his close friends. In fact, in a few month's time when his college shut down and he was facing the possibility of deportation it was these two roommates who urged him to seek other legal routes including asylum.

The understanding that South Asian/brown spaces are inherently homophobic and the recent news from the continent about how Syrians and other Muslim migrants are changing the very character of Europe is one that needs to be challenged. Whilst it is true brown spaces like any other spaces could be homophobic, the idea that all South Asian spaces are by default homophobic operates as a technology of racism, via which queer Muslim bodies are displaced and perpetually caught between ethnic enclaves and gayborhoods. For a working-class man like Usman the strongest sense of non-belonging for him was not the South Asian neighborhoods of East Ham in London but rather the liberal minded Soho. Usman found a sense of safe place with his room-mates and felt that his body was out of place (Kunstman and Miyake, 2008) in the gay bars of Central London. In the next section we will look at artist Raisa Kabir's work who challenges these very ideas and shows how South Asian/brown spaces can also function as a safe queer space.

\subsection{Queer/brown spaces}

Kabir is a London based artist, a writer, and weaver who also describes herself as a 'South Asian queer disabled femme' and this politi - cal identity resonates in most of her work. For the purposes of this paper we concentrate on her most recent photography exhibition - In/Visible Space: Reflections on the realm of dimensional affect, space and the queer racialised self which was held at Rich Mix, a cultural space in the multiracial Bethnal Green area of East London. Kabir's use of the slash or dividing bar in the title of her exhibition is in some way an echo of Roland Barthes (1974) use of the sign in his seminal text $S / Z$ which is central to his structuralist account of cultural signs. The slash in Kabir's title is both a way of defining a paradigm and also stating the oppositional nature of the two words-visible and invisible which are so closely associated with queer representation and queer communities of colour in the United Kingdom. Barthes writing about the slash says:

'it is the slash of censure, the surface of the mirror, the wall of hallucination, the verge of antithesis, the abstraction of limit, the obliquity of the signifier, the index of the paradigm, hence of meaning' (Barthes, 1974: 107).

What Barthes articulates and what Kabir's title of the exhibition demonstrates is the collision of the two words-visible and invisible. The slash in Kabir's exhibition title indexes this paradigm of signification and the possibility of the various ways through which the slash makes possible and legible the various registers of visible and invisible existence that South Asian queers in United Kingdom embody. Through this same line of inquiry it can also be then said that the slash also heralds the possibilities of the unification of these two modes of being that emerges from South Asian queer existence in the United Kingdom.

The exhibition featured a series of visual essays which asked self identified queer and trans" South Asians what they feel about visibility and safety within the various spaces around the city of London which they inhabit. Kabir does not simply seek to find such spaces of existence but rather also goes questions and asks if such spaces are imagined or can actually be created. In this article we specifically examine two photo montages from Kabir's collection which are based in two diverse kinds of space-faith based space (Maryam) and a public neighbourhood (Yasmin). Sexuality is constantly being mapped and remapped across various social and cultural landscapes. As Johnston and Longhurst (2010: 2) argue 'space, place and sex are inextricably linked'. The ways in which queer bodies occupy particular spaces within particular times is both a personal as well as a political choice. Johnston and Longhurst (2010: 3) further argue that sexed bodies are mapped and connected not just through bars, casinos and clubs but through all spaces. We are in agreement with them that 'there are no spaces that sit outside of sexual politics. Sex and space cannot be decoupled'. Gopinath's work on South Asian queer diasporas is also of particular importance here. Gopinath for instance writes that it is the queer South Asian figure's stubborn failure to cohere and neatly fit an identity template that has helped it survival within 'cracks and fissures' (Gopinath, 2005: 153) of a pan South Asian identity. Kabir's two montages allow us to dissect the ways in which queer sexual diasporic identities are inextricable from the continuing histories of colonialism, racialisation/racism and the growing Islamophobia in Europe post 9/11 and the recent mass migration from war torn areas of Middle East and Western Asia. 


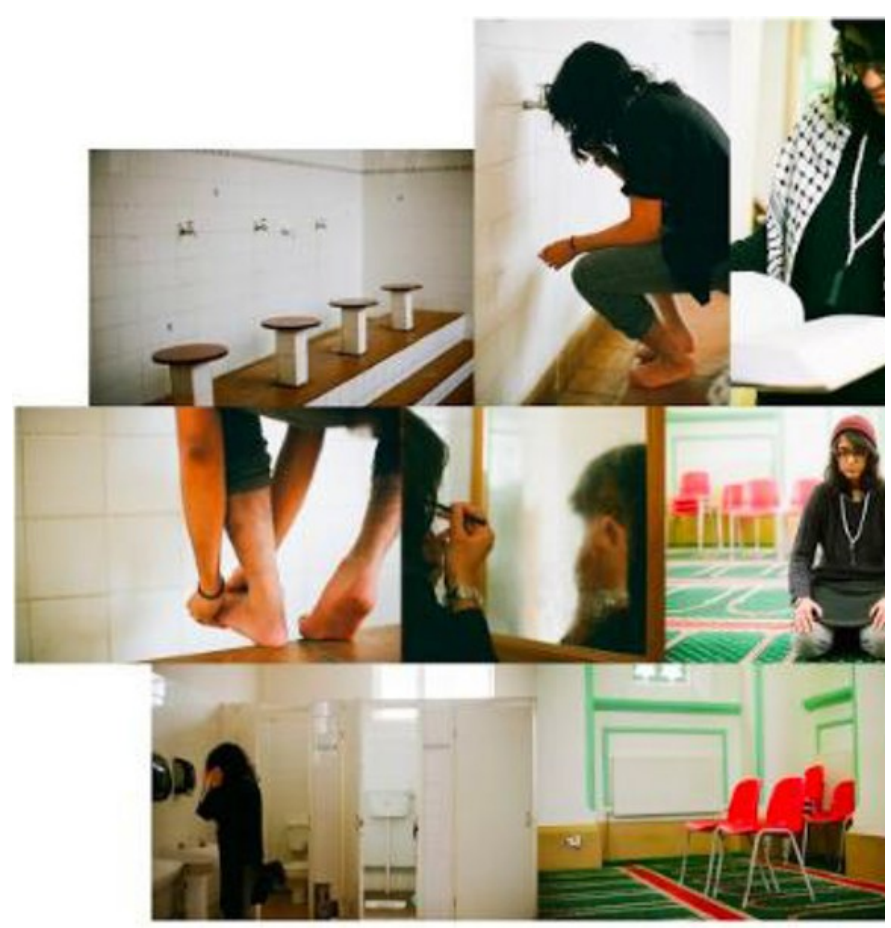

In the first montage, Kabir photographs Maryam, a self identified queer Muslim feminist activist in Shah Jahan mosque, a predominantly Pakistani mosque. Faith has remained an under analysed area in studies of queer space. Rodriguez and Oullette (2000) for example argue that there are several strategies through which queer people reconcile or reject the two parts of their identity-religious and sexual, which also has a powerful effect on how faith based spaces are usually viewed. Kabir places Maryam in a (male) public space of a mosque as a queer woman to pray. In a conversation with Kabir, she points out that Maryam's sartorial choices was very important to understand this montage. Her choice to leave behind the hijab and instead cover her hair with a topi like most Muslim men was not just standing up to gendered expectations but also her way of understanding and negotiating her queer sexuality within this faith based space.

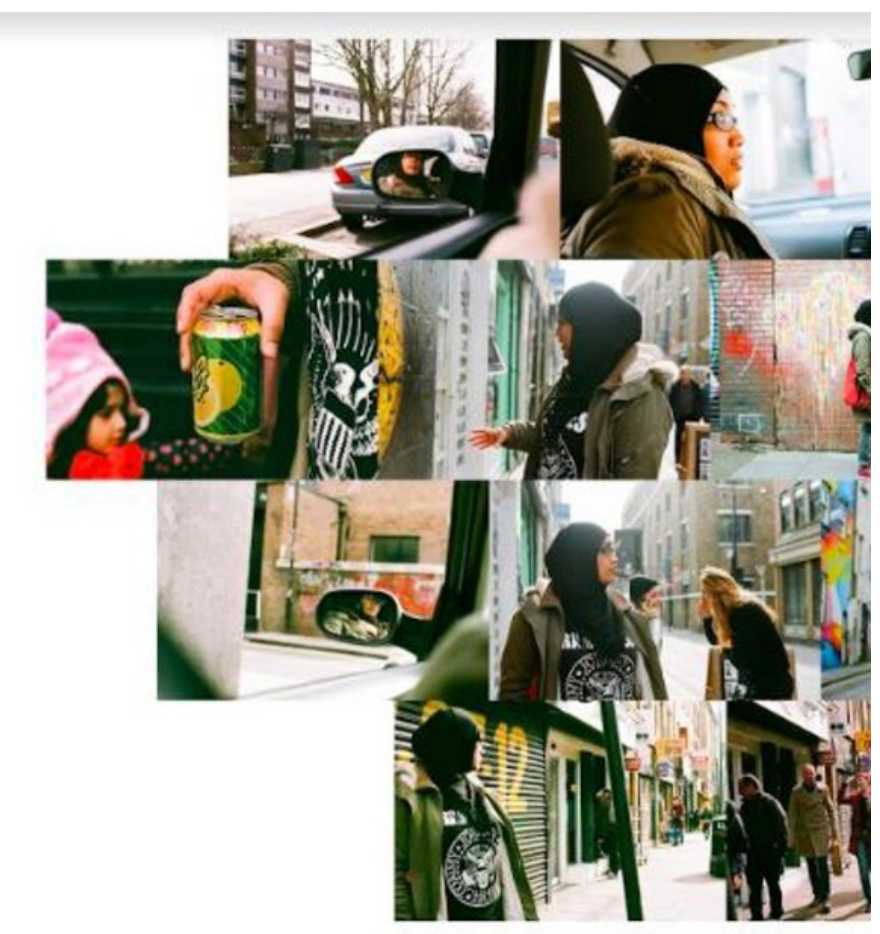

The second montage is markedly different from the first one. Here we see Yasmin who identifies as bisexual in the Brick Lane area of East London. Brick Lane as many who have read Monica Ali's novel of the same name and the subsequent film that followed would know is an area of East London which is associated with mostly Bangladeshi migrants who moved here during the 1970's and 1980's. Brick Lane of course has a much richer history having been an area that has always welcomed migrants and those fleeing persecution-from the French Huguenots, the Jewish community and finally the Bangladeshis. The current Brick Lane mosque is a testament to the changing and shifting boundaries. Established in 1743, it first served as a Protestant chapel, followed by it becoming a synogogue in the late 19th century and finally a mosque in 1976. Kabir explains that Yasmin chose this place to be photographed so she could 'be herself' and anonymous amongst the many graffiti and public artwork in this rapidly changing area of gentrification. She explained this offered her invisibility from the neighboring Whitechapel area where her hijab and Muslim clothes would make her hypervisible. The shots of the interior of the car, cans of beer also signify what becomes a safe queer space for Yasmin. Similar to Maryam, her choice of clothes-the hijab over her jeans and t-shirt also signify hybridity of her sartorial identity which as Kabir explained she calls 'q-wearing'.

Kabir's montages we would argue furthers the conversation started by the British Asian photographer Parminder Sekhon almost a decade ago, whose work Gopinath (2005:192) describes as 'rescue[ing] queer female desire from a logic of impossibility by installing it at the very heart of the home as both national and diasporic space'. The layers of oppression faced by queer Muslims in the United Kingdom are multiple who are targets of hate and discrimination based on their sexuality (heterosexual members relying on both heteronormative cultural homophobia and religious edicts) but also discriminated within the larger mainstream queer spaces because of their race and religion. Kabir's work tries to break the stereotype of the incompatibility between Islam and homosexuality and it would be good to remember Samar Habib's (2010: 1vi) argument that 'the Muslim world is no more or less rational 
than the Western world.' Ferdi Thajib (2016) in their study of queer Indonesians explained that affective practices of ambivalence is a strategy that is often used by queer Muslims. Whilst many of his research participants discuss feeling disconnected from bodily participation due to their complex experiences of faith and religion, they recognize and practice Islam through multiple affective improvisations. Kabir's images show that it is important to recognize that no culture or religion is homogenous or monolithic and marginal identities always find a way of coexisting and as such there is nothing exclusively Islamic about homophobia. As Usman explained to us, he has now learned to reconcile his sexuality and religious belief after all his 'god is merciful and he too is a creation of him'.

\section{Conclusion}

Our intention in this article has been to bring queer of color theory, feminist geopolitics and queer geographies in conversation with each other. In doing so, we argue that queer space is formed through racial erasures, and placing the embodied experiences of queer Muslim migrants at the center of our analysis reveals how queer racialized spaces are different in their location from white queer spaces. Recent scholarship in geographies of sexualities has argued that queer space does not merely exist in opposition to heteronormativity as a heroic and liberatory space. Rather, the task of critical geographers is to read how racialized, gendered, and nationalist norms comes to constitute queer space (Oswin, 2008). Browne, Brown, and Lim argue that queer space needs to be understood not simply as one that is structured through sexuality. "Rather, these everyday spaces intersect with various other scales of spatiality, including national, international and transnational spaces," (Browne et al., 2007: 3). Building upon these themes, throughout the article we have argued that queer Muslim subjects are framed as always outside the white gay spaces in Central London, and are required to disavow their ethnic-religious identities in order to be read as appropriately queer. However, our reading of Kabir's work reveals how "the queer Muslim movement... is the product of a complex set of struggles, identities, experiences and politics through a unique combination of religious, activist, and academic pursuits," (Rouhani, 2007: 179). Kabir's photograph attempts to place the queer Muslim subject within queer, Muslim, migrant neighborhoods of London. As we cross read her photographic visualizations with Usman's experiences with his fellow Muslim (straight) South Asian immigrants, we are offered a glimpse of how ethnic and religious identities might not necessarily be in conflict with sexual identity. Rather, the queer Muslim subjects attempts to maneuver ethno-racial enclaves as a way of shielding themselves from a Islamophobic and xenophobic British society.

Queer diasporic subjectivity is framed through structures of racism, colonialism, heteronormative nationalisms and global movements of capital and labor (Banerjea et al., 2018; Gopinath, 2005; Puar and Rai, 2004). The figure of the Muslim migrant comes to represent an aberration to liberal-modernity as promised by the enlightenment. Anxieties with Muslim migrants inform structural racism in the UK. However, the imagining of Muslim migrants as a heteronormative figure erases the racialized narratives of queer migrant subjects. In this article we presented three diverse texts related to queer Muslim subjects in the UK. In analyzing Rashid's A Touch of Pink we have argued that Islam is constructed as backward to the liberal modernity of Western Europe. Such imaginations about Islam accord a specific time and space configuration upon queer Muslim subjects. Queer Muslim subjects such as Alim (the protagonist of the film) stand against the queer progressive narratives of Western Europe. Alim is not 'out' to his mother, and in this way his closet comes to represent a different time and place configuration, one that is backward to the 'coming out' happy narrative of his British boyfriend Giles. Alim can only feel happiness through his orientation toward whiteness, represented through his enchantment with Cary Grant. Sexuality is conferred upon the racialized subject through his distance from Islam. Thus, queer Muslim subjects are always in a distance (somewhere else) either from their religion or their sexual desires. Secondly, we have argued that Alim's widowed mother is a queer figure since her desires cannot be accommodated within the heteronormative futurity of her religious and ethnic community. Both Alim and Nuru have to 'come out' in order to find a utopic queer horizon, one that is in distance from their religion and communities of origin. The disavowal of one's religious and ethnic identity is a spatialized process through which the cityscape of London metropolis is imagined as the gay center while the immigrant suburb is located on the periphery. Usman's narrative reveals that while he was seeking for an imagined gay space in London's gayborhoods, his religious identity and class position marks him as an outsider in these spaces. He is able to find some support from his South Asian roommates. Usman's story suggests that his travel in-between the city center and East London marks the way his body is out of place in the gayborhoods of London. Safe gay space is in fact a safe gay white space, whereas his South Asian roommates might provide him with a (fraught) space where his religion and sexuality is not in conflict with each other. The visual representations of immigrant Muslim spaces in the work of lesbian, feminist, disabled artist, Kabir holds potentials for re-spatializing queer Muslim desires by placing them within ethnic and religious landscape of London.

The three texts taken together offer a multifaceted view into how queer racialization works in the United Kingdom and the ways through which young queer Muslims have set about to reconcile their sexuality with their faith, challenging some of the attitudes which sees queer sexuality incompatible with one's racial/ethnic and religious identity. What is important to recognize is how intercultural variances and lived actualities demand new forms of imagining and understanding which contests the view that navigating queer spaces in London require disavowal of one's ethnic and religious origin. Such disavowals can be questioned by reimagining new modes of queer (Muslim) belonging.

\section{References}

Ahmed, S., 2010. Happy objects. In: Gregg, M., Seigworth, G. (Eds.), The Affect Theory Reader. Duke University Press, Durham, NC.

Anderson, B., 1983. Imagined Communities: Reflections on the Origin and Spread of Nationalism. Verso, London.

Banerjea, N., Dasgupta, D., Dasgupta, R.K., Grant, J., 2018. Friendship as Social Justice Activism: Critical Solidarities in a Global Perspective. Seagull, London/Kolkata. Barthes, R., 1974. S/Z (Trans: Richard Miller). Hill and Wang, New York.

Boyce, P., Dasgupta, R.K., 2017. Utopia or elsewhere: queer modernities in small town West Bengal. In: Kuldova, T., Varghese, M. (Eds.), Urban Utopias. Palgrave Macmillan, London.

Browne, K., Lim, J., Brown, G., 2007. Geographies of Sexualities: Theory, Practices, and Politics. Surrey. Ashgate, England and VT, USA.

Butler, J., 2010. Frames of War: when Is Life Grievable? Verso, London and New York. Chavez, K., 2013. Queer Migration Politics: Activist Rhetoric and Coalitional Possibilities. University of Illinois Press, Urbana.

Dasgupta, R.K., 2016. Remembering Benedict Anderson and his influence on South Asian studies. Theor. Cult. Soc. 33 (7-8), 334-338.

Dasgupta, R.K., 2017. Digital Queer Cultures in India: Politics, Intimacies and Belonging. Routledge, London.

Dasgupta, R.K., 2018. Coming out isn't as easy as you think for a LGBT+ person of colour. IndependentAppears at http://www.independent.co.uk/voices/ lgbt-rights-movement-marriage-coming-out-disregard-queer-trans-people-ethnic-minorities-a 8 html.

Dasgupta, R.K., Gokulsing, K.M. (Eds.), 2014. Masculinity and its Challenges in India, (Jefferson.NC: McFarland).

DasGupta, D., 2014. Cartographies of friendship, desire, and home: notes on surviving neoliberal security regimes. Disabil. Stud. Q.34 (No 4), Appears at http://dsq-sds.org/ article/view/3994/3789.

Dudrah, R., 2012. Bollywood Travels: Culture, Diaspora and Border Crossings in Popular Hindi Cinema. Routledge, London.

Gorman-Murray, A., 2009. Intimate Mobilities: emotional embodiment and queer migration. Soc. Cult. Geogr. 10 (4), 441-460.

Gorman-Murray, A., 2007. Rethinking queer migration through the body. Soc. Cult. Geogr. $8(1), 105-121$.

Gopinath, G., 2005. Impossible Desires: Queer Diaspora and South Asian Public Cultures. Duke University Press/Kolkata: Seagull Books, Durham, NC.

Habib, S., 2009. Female Homosexuality in the Middle East: Histories and Representations. Routledge, London. 
Habib, S., 2010. Islam and Homosexuality. vol. 2, ABC Clio, Denver, CO.

Hall, S., 1988. The Hard Road to Renewal: Thatcherism and the Crisis of the Left. Verso, London.

Hall, S., 1993. Encoding/decoding. In: During, S. (Ed.), The Cultural Studies Reader. Routledge, New York, pp. 90-103.

Johnston, L., Longhurst, R., 2010. Space, Place and Sex: Geographies of Sexualities. Rowman and Littlefield, Lanham.

Kunstman, A., Miyake, E., 2008. Out of Place: Interrogating Silence in Queerness/Raciality. Raw Nerve Books, York.

Lubheid, E., 2008. Queer/migration: an unruly body of scholarship. GLQ A J. Lesbian Gay Stud. 14 (2-3), 169-190

Mowlabocus, S., 2010. Gaydar Culture: Gay Men, Technology and Embodiment. Ashgate, Surrey, England and VT, USA

Myslik, W., 1996. Renegotiating the social/sexual identities of places: gay communities as safe havens or sites of resistance. In: Duncan, N. (Ed.), Bodyspace: Destabilising Geographies of Gender and Sexuality. Routledge, London, pp. 155-168.

Nagar, I., Dasgupta, D., 2015. Public koti and private love: section 377, religion, perversity and lived desire. Contemp. S. Asia 23 (4), 426-441.

Oswin, N., 2008. Critical Geographies and the uses of sexuality: deconstructing queer space. Prog. Hum. Geogr. 32 (1), 89-103.

Pain, R., 2009. Globalized Fear? Towards an emotional geopolitics. Prog. Hum. Geogr. 33 (4), 466-486.

Pain, R., Smith, S., 2008. Fear: Critical Geopolitics and Everyday Life. Ashgate, Hampshire, England and VT, USA.
Pain, R., Staeheli, L., 2014. Introduction: intimacy, geopolitics and violence. Area 46 (4), 344-347.

Puar, J., Rai, A., 2004. The remaking of a model minority: perverse projectiles under the specter of (counter) terrorism. Social Text, 8022 (3), 75-104.

Puar, J., 2007. Terrorist Assemblages: Homonationalism in Queer Times. Duke University Press, Durham, NC

Rodriguez, E., Oullette, S., 2000. Gay and lesbian christians: homosexual and religious identity integration in the members and participants of a gay- positive church. J. Sci. Stud. Relig. 39 (3), 333-347.

Rouhani, F., 2007. Religion, identity and activism: queer Muslim diasporic identities. In: Browne, K., Lim, J., Brown, G. (Eds.), Geographies of Sexualities: Theory, Practices, and Politics. Ashgate, Surrey, England and VT, USA.

Thajib, F., 2016. Kaleidoscopic feelings: faith narratives among Indonesian Muslim queers. Emotion, Space and Society 25, 127-135.

Tolia-Kelly, P.D., 2006. Affect-an ethnocentric encounter? exploring the 'universalist' imperative of emotional/affective geographies. Area 38 (2), 213-217.

Valentine, G., 2001. Social Geographies: Space and Society. Pearson, Harlow.

Yip, A., 2004. Embracing Allah and Sexuality? South Asian non heterosexual Muslims in Britain. In: Jacobsen, K., Kumar, P. (Eds.), South Asians in the Diaspora. Histories and Religious Traditions. Brill, Leiden, pp. 294-310.

Yip, A., 2015. When religion meets sexuality: two tales of intersection. In: Dickey Young, P., Shipley, H., Trothen, T. (Eds.), Religion and Sexuality: Diversity and the Limits of Tolerance. University of British Columbia Press, Vancouver, pp. 119-140. 